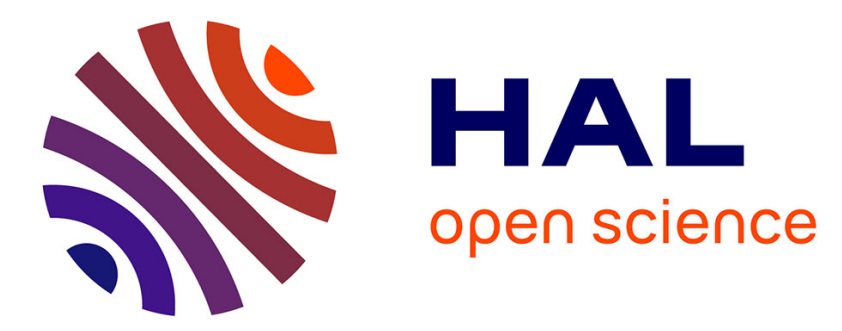

\title{
Convergence and conflict: anthropology, psychiatry and feminism in the early writings of Madeleine Pelletier (1874-1939) \\ Felicia Gordon
}

\section{- To cite this version:}

Felicia Gordon. Convergence and conflict: anthropology, psychiatry and feminism in the early writings of Madeleine Pelletier (1874-1939). History of Psychiatry, 2008, 19 (2), pp.141-162. 10.1177/0957154X07082616 . hal-00570910

\section{HAL Id: hal-00570910 https://hal.science/hal-00570910}

Submitted on 1 Mar 2011

HAL is a multi-disciplinary open access archive for the deposit and dissemination of scientific research documents, whether they are published or not. The documents may come from teaching and research institutions in France or abroad, or from public or private research centers.
L'archive ouverte pluridisciplinaire HAL, est destinée au dépôt et à la diffusion de documents scientifiques de niveau recherche, publiés ou non, émanant des établissements d'enseignement et de recherche français ou étrangers, des laboratoires publics ou privés. 


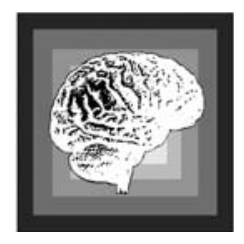

\title{
Convergence and conflict: anthropology, psychiatry and feminism in the early writings of Madeleine Pelletier (1874-1939)
}

\author{
FELICIA GORDON ${ }^{\star}$ \\ Anglia Ruskin University, Cambridge
}

\begin{abstract}
This paper reviews the early career and psychiatric writings of Madeleine Pelletier (1874-1939), between 1901 and 1906. Pelletier, a committed feminist and socialist, was the first woman to remove the barriers to women entering the French psychiatric profession, successfully passing the examination for the l'internat des hôpitaux psychiatriques in 1903. Her involvement in La Société d'Anthropologie de Paris and the Institut Général de Psychologie provided a forum for her interest in psychology, both normal and abnormal. She turned increasingly to sociological explanations for mental illness, unwilling to accept the determinism inherent in degeneration theory. Although her career in psychiatry was cut short in 1906, her training and her debating skills, honed in the rationalism of the scientific and Free Masonic societies that she frequented, stood her in good stead in her subsequent career as a political militant.
\end{abstract}

Keywords: anthropology; feminism; France; psychiatry; psychology

This paper examines the early work of the radical socialist and feminist, Madeleine Pelletier (Fig. 1), in anthropology and psychiatry between 1901 and 1906, a period of intense productivity both in her published research and feminist/socialist militancy. The first woman to sit and be successful in the examination for l'internat des hôpitaux psychiatriques in 1903, Pelletier had been active in the Société d'Anthropologie de Paris (hereafter SAP) from at least 1900 , attending lectures and publishing a number of papers on craniometrical subjects. She wrote five anthropological articles (Marie and Pelletier, 1905a; Pelletier, 1900, 1903a; Pelletier and Marie, 1901; Vaschide and Pelletier, 1904).

\footnotetext{
* Address for correspondence: 1 Latham Close, Cambridge CB2 7EL, UK. Email: fmgordon@btinternet.com
} 


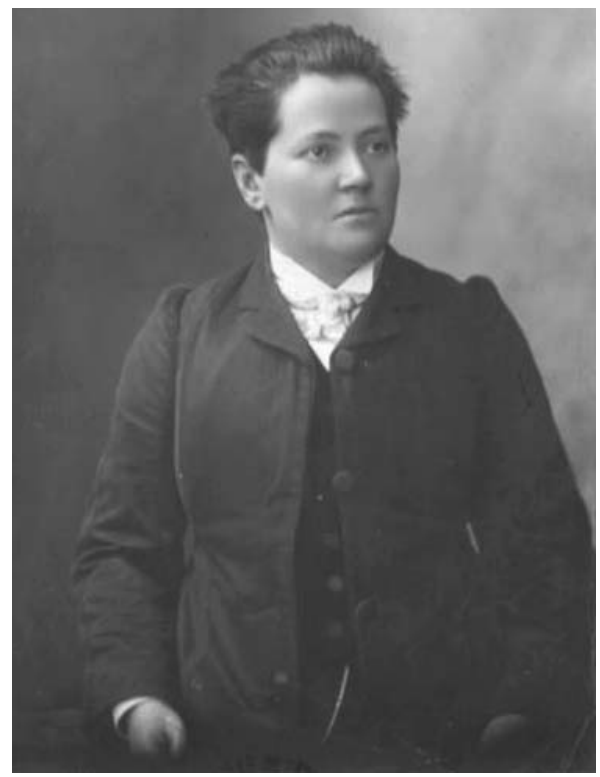

FIG. 1. Madeleine Pelletier, c.1906 (courtesy of the Bibliothèque Marguerite Durand)
Her psychiatric writing included her medical dissertation, which ran into two editions (Pelletier, 1903b, 1904b), and three articles in the Bulletin of the Institut Général de Psychologie (hereafter IGP), founded in 1901 (Pelletier, 1904a, $1905 b, 1906 b)$, as well as an article published in Archives de Neurologie (Pelletier, 1906a), one in Archives de Biothérapie (Pelletier and Marie, 1905) and one for the Revue de Psychiatrie et de Psychologie Experimentale (Marie and Pelletier, 1905b).

Charles Sowerwine (2003) has demonstrated how the racial and sexual hierarchies informing anthropology in Third Republic France determined the parameters of Pelletier's first period of research. I will be examining the more liberating intellectual effects of evolutionary theory in developing her feminist ideas and its impact on her psychiatric work. Neo-Lamarckian transformism, as filtered through the writings of Charles Letourneau, her mentor at the Société d'Anthropologie, fitted into a socialist, meliorist agenda (Hammond, 1980). ${ }^{1}$ Although Pelletier's commitment to socialism and feminism had its roots in her own experiences of material and emotional deprivation, she first found a language for her instinctive radicalism in the politicized world of the newer scientific societies.

\section{Biography}

The primary biographical sources for Pelletier's early life are found in her unpublished manuscript, 'Doctoresse Pelletier, mémoires d'une féministe', ${ }^{2}$ and a further fragment dictated to her friend, Hélène Brion, 'Anne, dite Madeleine Pelletier' $(1939)^{3}$ in the last year of her life, and an extensive police dossier dating from 1916 (AN, 1916; Gordon, 1992). She remained an object of police surveillance throughout her life, culminating in her arrest in 1939 for assisting in performing an abortion. This led to the tragic irony of her incarceration, due to 'incapacity', in the mental hospital of Perray Vaucluse where she had once trained as a psychiatric intern and where she died within a year of her arrest (Gordon, 1990: 221-35).

Anne Madeleine was born on 18 May 1874 to parents who eked out a marginal existence in a tiny fruit and vegetable shop near Les Halles. Her father, a cab driver, seems to have held radical, anti-clerical views. Her mother, Anne, 
née Passavy, was by contrast fanatically religious, but a terrible housekeeper. The family house, now demolished, consisted of one room on each of its two floors. It was always, Pelletier remembered, filthy and squalid. Sent to a convent school, where she excelled at her lessons, she was shunned on account of the lice dropping from her hair and clothes. Madeleine rebelled against authority when she was about thirteen and, according to her memoir, frequented anarchist and feminist groups. Nothing more is known of Pelletier until 1897, when aged twenty-three she passed the baccalaureate in philosophy and literature, having been granted a scholarship by the City of Paris for her studies. How she made the transition from virtual street urchin to successful examination candidate in the highly competitive intellectual culture of Third Republic France is one of the continuing mysteries surrounding her. Her connections among Freemasons and in feminist circles were indubitably of great assistance. In 1898 she began her studies at the Faculté de Médecine, which she completed in 1903, in spite of some set-backs in examinations. Although her professors noted her 'assiduity', her results had not been spectacular. However her dissertation, L'Association des idées dans la manie aigüe (Pelletier, 1903b), discussed below, was granted the highest mark. Her work with, and interest in, psychiatric patients and in contemporary theories on mental processes of both the sane and insane preceded her formal psychiatric internship by at least three years. In addition, during the five years of her medical studies, Pelletier had frequented the Anthropological Society of Paris, becoming a protégée of Professors Charles Letourneau and Léonce Manouvrier (Gordon, 1990: 31-41; Sowerwine and Maignien, 1992: 32-3). Under their aegis she published four articles in the Bulletins de la Société d'Anthropologie de Paris on craniometrical measurements. The most significant of these, in the light of her political/feminist interests, was a study of Japanese skeletons, demonstrating that the alleged superiority of male over female skeletal development was illusory (Pelletier, 1900).

\section{Anthropolgy and feminism}

Pelletier's early career was indubitably assisted by her attendance at the Freemasonic lodge, le Droit Humain, where she was exposed to radical ideas and a network of feminist, socialist and anarchist thinkers (Allen, 2003; Gordon, 1990: 21-44; Sowerwine and Magien, 1992: 53-64). Freemasonry offered a forum that enabled women to train in debate and public speaking (Pelletier, 1905a). It was here that she met prominent members of the SAP and feminists like Maria Desraimes, Céline Rénooz and Clémence Royer (18301902). Yet the last named, a woman remarkable as a feminist, as the first female member of the SAP and as the first French translator of Charles Darwin's The Origin of Species (Darwin, 1862), forms a noticeable omission in Pelletier's written recollections. Given Royer's overt feminism and her many contributions both in debates and articles to the SAP, Pelletier's silence on her predecessor is intriguing. Pelletier had almost certainly read Royer's translation of 
Darwin rather than labouring through the English text. ${ }^{4}$ Royer's Darwinian critics accused her of playing fast and loose with Darwin's text and advocating her brand of neo-Lamarckian evolutionary theory (Laurent, 1987, 1989; Stebbins, 1974), which, in principle, should have attracted Pelletier. Royer, who died in 1902 at the age of 74, was no longer active in the SAP when Pelletier attended its meetings, but her reputation as Darwin's translator, as an eugenicist and as a feminist, who advocated a return to matriarchy, would certainly have been known to Pelletier (Royer, 1895).

Royer's position as a woman in the SAP exemplified many of the disabilities against which Pelletier, a feminist of the next generation, would also struggle. For their male colleagues, the SAP provided a forum for debate and for the publication of scientific papers, forming part of a professional network leading to university teaching posts. As a woman, Royer could publish, but not be considered for professional advancement in the field of anthropology - the same barriers which later confronted Pelletier (Harvey, 1997: 123). Pelletier's abandonment of direct activity with the SAP related partly to her increasing unease with the anthropological paradigm, but also to her realization that anthropology could not offer her a sustainable career (Sowerwine, 2003).

Royer's brand of separatist feminism emphasized gender difference, women's moral superiority and the necessity of human inequality as a spur to social improvement (Fraisse, 1985; Harvey, 1997). It is in relation to these ideas that one can understand Pelletier's silence in regard to Royer, even if the latter had not ceased to be active in SAP by the time Pelletier frequented its meetings at the turn of the century. Both Pelletier's socialist commitment to equality and her conviction that male/female difference did not extend to intellectual difference precluded a meeting of minds on the direction that feminism should take. Nor did Pelletier believe that women were morally superior to men any more than intellectually inferior. On the population question, Pelletier was entirely opposed to Royer. She argued throughout her career that women's control over their own reproduction was the key to their enfranchisement. Smaller populations were not necessarily a disadvantage in a technologically advanced world. Thus Royer, though a major feminist precursor in anthropology and a model for women aspiring to achieve in scientific fields, would have represented one of the many aspects of feminist thought from which Pelletier disassociated herself.

In one important respect, Pelletier's first anthropological article (Pelletier, 1900), a comparative study of male and female Japanese skeletons, took up a theme that seems to have defeated Royer, namely Gustave le Bon's contention that women's brains, being smaller than men's, were therefore inferior and that women's social inferiority was a natural and correct consequence of this measurable fact (Harvey, 1997; Nye, 1975). As a disciple of Léonce Manouvrier (Hecht, 2003; Sowerwine, 2003), who in turn followed in the liberal socialist tradition of Charles Letourneau, Pelletier developed his critique of value-laden anatomical difference. In 1883 Manouvrier had published a 
study demonstrating that if one calculated the ratio of brain weight to body weight, women were superior. In his 'Anthropologie des sexes', Manouvrier (1903) argued, with Le Bon and Broca in his sights, against notions of the intrinsic inferiority of women. He pointed to the way in which prejudice, even among 'enlightened' persons, can take on the mantle of scientific objectivity:

Theologians had once asked whether women had a soul. Scientists were very close, a few hundred years later, to denying them human intelligence. One can read in some of the most prestigious collections of scientific writings, many reflections and conclusions arguing that seemingly in the evolution of the human species, woman remains, in many respects, especially in her cerebral development and various morphological characteristics of the skull and limbs, in a state very little distanced from anthropoid apes. (Manouvrier, 1903: 406)

Yet Manouvrier, like many other French socialists, believed that the elimination of social inequality would mean an end to the need for feminism, a conclusion with which Pelletier (1904c: 4) profoundly disagreed. Nevertheless, Manouvrier's views certainly do not amount to anti-feminism as has sometimes been alleged (Sowerwine, 2003; Stewart, 2000: 32). On the contrary, Hecht (2003) argues that Manouvrier rejected the sterile conclusions of mere measurement in studying sexual or racial difference. Though he may not have relished the idea of war between the sexes, or competition in the workplace, he conclusively demolished anthropological arguments for women's innate inferiority. ${ }^{5}$ Pelletier's work, under Manouvrier's aegis, contributed to his effort, at that stage, not to disprove craniometrical systems of measurement, but the social conclusions too easily drawn from them. ${ }^{6}$ Both hoped to apply Lamarckian evolutionary models of passing on learned adaptation to counter the pessimistic doctrines of racial decadence and retrogression constructed by anthropologists on the right (Hecht, 2003).

\section{Psychiatry}

While still completing her medical studies (1901-02) Pelletier gained a post as interne suppléante (temporary or deputy intern) at the Villejuif Asylum, a post controlled by the medical faculty (not by competitive examination, which as a woman she would have been precluded from attempting), and fulfilled the clinical requirements for her medical degree at the St Anne Asylum (Sowerwine and Magnien, 1992: 38). At Villejuif she worked with Nicolas Vaschide with whom she collaborated on an ill-fated study of schoolchildren's intelligence (Vaschide and Pelletier, 1904; see also Gordon, 1990: 38-9; Pearson, 19027). At the St Anne Asylum, her professor was Alix Joffroy (1844-1908), who had been a student of Charcot. Pelletier's doctoral thesis, earned her the almost unheard-of commendation from the examining panel of 'extremement satisfaits' (Sowerwine and Maignien, 1992: 40), the highest praise the jury could 
award. Her published thesis went into two editions and was reviewed in the prestigious Revue Philosophique (Rogues de Fursac, 1904). ${ }^{8}$

L'Association des idées dans la manie aigüe et la débilité mentale (The Association of Ideas in Acute Mania and Mental Debility) (Pelletier, 1903b, 1904b) represents a wide-ranging philosophical and psychological inquiry into the nature of mental illness based on the assumptions of English associationist psychology. Pelletier argued that the laws of association, depending on resemblance or contiguity, are the basis of abnormal as well as of normal mental functioning. Thus, mental derangement or debility was not necessarily a sign of degeneracy. The mad were not a separate category, but part of a human continuum. If the laws of associationist psychology applied equally to the mad as to the sane, then an understanding of mental illness could be based on an analysis of patients' modes of connection and disconnection, e.g., their speech. As becomes clear in Pelletier's case studies, as well as accounts of subsequent patients, the 'mad' utterance of such patients held their own logic. She further demonstrated how normal people frequently hold totally irrational and incompatible ideas, without being considered mad.

In her study, Pelletier cited John Stuart Mill's, An Examination of Sir William Hamilton's Philosophy (1865), an attack on neo-Kantianism, Herbert Spencer's, The Principles of Psychology (1855), Pierre Janet's Les Obsessions et la psychasténie (Obsessions and Psychasthenia, 1898) and Bergson's Essai sur les données immédiates de la conscience (Essay on the Immediate Data of Consciousness, 1901). Janet's Les Obsessions et la psychasténie provided the psychological foundation for her thesis. Janet linked mental medicine with general psychology, morbid states with normal human thought, and was ranked as the founder of medical psychotherapy in France (Shorter, 2005: 148). He coined the term psychasthénie (psychasthenia) to indicate the weakening of patients' psychological functions. In this interpretation, mental illness is a result of 'weakening', or loss of will power, but the laws of associations still apply, though in a confused form. Janet's medical psychotherapy resembled Pinel's and Esquirol's 'moral treatment', assuming as it did that it was possible in many cases to ameliorate a patient's condition by improvements in their diet and by listening to their anxieties. Although not dismissing heredity as a major factor in psychasthenia, Janet did not give degeneracy theories the last word (Janet, 1898: xxiv).

The other key psychologist underpinning Pelletier's dissertation was Frédéric Paulhan (1836-1931), who particularly emphasized systematization in mental processes, a sort of psychological atomic theory (Paulhan, 1887:3). Systematic association for higher order thought, linked to the law of systematic inhibition, permits concentration on one object and the elimination of extraneous ideas. Thus, superior mental processes are explained by the synthetic grouping of mental states into systems. If, however, this systematization does not take place, incoherence, hysteria, etc., are the result (Pelletier, 1904b: 10-11). 
Pelletier was also indebted to a review by G. Dumas of Janet's Travaux $d u$ laboratoire de psychologie de la Salpêtrière, published in 1898 (Dumas, 1899). Dumas held a post at St Anne and is mentioned in her text with reference to patient interviews. Janet's research, as Dumas notes, was based in Charcot's laboratory at the Salpêtrière, primarily studying hysterics. Janet believed that the aetiology of hysteria could be explained by the power of emotional shocks, which had, he thought, been insufficiently recognised (Dumas, 1899: 651). Patients' recovery, according to Dumas/Janet, depended on regaining the directive impulse. In psychiatry this cure would stem from the clinician; in religion similar states, Dumas suggested in an anti-clerical aside, were traditionally effected by abandoning one's freedom to obedience and to dogma.

Although Pelletier's L'Association des idées follows Janet/Dumas in seeing breakdown in concentration as one of the main functions that allows synthesis or systematization, on the issue of causes, that is the aetiology of mental collapse, Pelletier at this stage differs markedly from Janet. Her mental map, setting out a hierarchy of strong vs. weak states, largely excludes mention of the emotions. She asserts that the laws of association rule all aspects of the mind: contiguity, contrast, resemblance and the systematic associations that produce synthesis. The higher order of mental activity (the strong) involves concentration; the lower order (the weak) she characterizes as 'rêverie', daydreaming. If this is the realm of emotion, though Pelletier does not explicitly say so, it seems to deny what Janet and Dumas posit; namely that the power not the weakness of emotional charges are what can dislocate the higher functioning of mental processes.

The intriguing question then arises: why did she virtually omit Janet's theory of the emotions from her descriptions? One possibility may have to do with Janet's source material. As already mentioned, he based much of his study on the hysterics and psychasthenics at the Salpêtrière with the result that most of his examples were women. Pelletier, still only a student in psychiatry and not in a position directly to challenge the sexual stereotyping of this class of patients, avoids, I suggest, the whole realm of emotion as a motor for mental illness because women both traditionally and now in scientific circles, were deemed constitutionally more emotionally fragile than men. ${ }^{9}$ Her first avowedly feminist article, published in 1904, the year following her dissertation, directly confronts this medical prejudice: 'Women have also been accused of inferiority of the will as well as of the moral sense. Women are supposedly, as one says today, psychasthenics (neurotics)' (Pelletier, 1904c: 5).

Pelletier's down-playing of the emotions in the mental associationist map, which she draws in her dissertation, implicitly recognizes the value-laden trap of emotion consigned to the feminine gender. So although Janet's theory of emotional shocks, long pre-dating Freud, might have much to recommend it, Pelletier initially appears to replace it with a somewhat mistily expressed theory of unknown causes of a physical origin, probably to be found in brain lesions (Pelletier, 1904b: 121-2). She maintains a strictly rationalist and 
materialist position in part, it may be conjectured, as evidence of her own undoubted capacity as a woman to attain the same rational heights as her male colleagues. However, in one of her last psychiatric articles (Pelletier, 1906a), she significantly modifies her position, in a short but telling case study, 'Folie et choc moral'.

The review of Pelletier's thesis (Rogues de Fursac, 1904) was less laudatory than the comments of her examiners, revealing deeply held differences of view in psychiatric theory and practice. Rogues de Fursac, who became médecin chef at the Ville Evrard Asylum in 1913, was the author of a statistical study of the hereditary antecedents of patients with general paralysis (Rogues de Fursac, 1914), and a proponent of theories of the hereditary causes of insanity, especially in general paralysis. He subscribed to the the degeneration theory, which remained the dominant aetiological model until the 1930s (Ward, 2002: 4). Rogues de Fursac attacks Pelletier's definition, or lack of it, of 'mania', which she applied to a whole range of psychiatric illnesses, some of which, such as the incoherence of dements précoces, showed no discernible laws of associative links (Rogues de Fursac, 1904: 673). The fact that he reviewed even if unfavourably, the thesis of a relatively unknown newcomer to the psychiatric field, reflects wider preoccupations in early twentieth-century psychiatry seeking a comprehensive and unified explanation of mental pathology (Ward, 2002: 2). In this he did not differ from Pelletier. He sought to prove the hereditary basis for general paralysis, a theory already being challenged by Alfred Fournier's thesis in 1879 of the syphilitic origin of general paralysis, supported by the Bordet-Wasserman Test in 1907, but resisted until definitive proof of trepanna in the cerebral cortex of general paralytics in 1913 by the psychiatric profession (Quétel, 1990). Behind Rogues de Fursac's negative review of L'Association des idées was his concern that, by eliding normal and abnormal states, Pelletier down-played the definitive role of heredity.

In 1902 Pelletier had attained prominence by launching a successful campaign to allow women to sit the public examination for the post of psychiatric intern, from which they were debarred by statute. This was her first public feminist campaign for which she enlisted the good offices of La Fronde, the feminist newspaper, and the support of her supervisor at Villejuif, Dr Edward Toulouse. The government having belatedly given permission for women candidates to sit the examination, in 1903 Pelletier took it and passed, coming sixth out of eleven candidates. Her contemporary, Constance Pascal, passed eighth in the same year (Gordon, 2006: 163-4; Sowerwine and Maignien, 1992: 42). During Pelletier's internship (1903-06), she wrote and published at least six articles based on her psychiatric work, one attacking Lombroso's theories on genius and her first feminist broadside, based on her work in psychology and psychiatry.

Three of Pelletier's psychiatric articles published in the Bulletin de l'Institut Général Psychologique were delivered at meetings of the Société de Psychologie, the first psychological society in France. It had a complex history (Parot, 2000). 
Originally the Institut Psychique International, under the direction of Pierre Janet, reported on experiments aimed at gaining a scientific understanding of phenomena such as telepathy, telekinesis and the powers of mediums. By 1901 it attracted both psychiatrists like Janet and Charcot and anthropologists like Manouvrier. Papers submitted by anthropologists, psychiatrists and psychologists explored diverse areas: animal psychology, moral and criminal psychology, ethnography and psychical research, which became a more dominant topic from 1904 onwards when discussion centred on an attempt to verify the powers of the medium Eusapia Paladino. Nevertheless, when Pelletier published her articles in the society's bulletin from 1904-06, the empirical, positivist and social reformist bases of the society's investigations were still predominant. Indeed even its psychic research elements, if colourful rather than rigorous, were based on positivist principles. (Lefebvre, 2002). ${ }^{10}$

Of the six articles Pelletier wrote in this period, three discuss auditory or tactile hallucinations (Pelletier, 1904a, 1905b, 1906b). Three others, are clinical, anatomical or therapeutic studies undertaken with Dr Marie, Médecin en Chef de l'Asile de Villejuif (Marie and Pelletier, 1905a, 1905b; Pelletier and Marie, 1905). Although they vary in subject matter, all are consistent in arguing for the somatic origins of mental illness (Pelletier, 1905b).

Most of Pelletier's published articles were initially presented as papers given before professional colleagues. Pelletier's debating experience in Freemasonic societies stood her in good stead as one of the very few women in this scientific milieu. Thus on 6 May 1904 Pelletier presented her paper, 'L'Echo de la pensée et la parole intérieure' (The echo of thought in interior speech) before the Société de Psychologie. Present were a number of psychiatric and anthropological notables, among them Professors Manouvrier and Janet. Pelletier's paper sought to link the mental process of thinking in words of normal people with abnormal states, either the intense auditory or visual anxieties of psychasthenia, or the exteriorized voices heard by patients suffering from paranoia. What distinguishes 'normal' states of individuals who have recourse to interior speech, often at high levels of concentration and the voices heard by psychasthenics or paranoiacs, for example, is that the latter apply this auditory thinking to everyday objects (Pelletier, 1904a: 460).

A patient with persecution complexes, though far more confident or aggressive than the psychasthenic, who is a mass of doubts, is equally cut off from the exterior world, suffering a profound sense of disquiet. Yet the paranoiac exhibits that 'echo of thought', which occurs also in the process of normal reflection as interior speech (Pelletier, 1904a: 461-3).

In the discussion following her paper, objections were raised by Messieurs Janet, Manouvrier and Séglas in relation to Pelletier's linking together of what they declared were disparate mental conditions; they also expressed unease about the continuum approach between normal and abnormal that Pelletier had employed. Nonetheless, though a neophyte in the field, Pelletier was able 
to respond to criticisms with spirit, demonstrating poise and self-confidence before her distinguished audience.

'Les membres fantômes chez les amputés délirants' (The phantom limb syndrome in mad amputees; Pelletier, 1905b) links these patients' overall delusional state and the 'normal' illusion of the phantom limb syndrome. Among amputees the illusion, she notes, is one of extraordinary intensity, though what is felt varies - sometimes the whole missing limb, sometimes the extremities, produce sensations. All her patients were unanimous in asserting the reality of the sensations experienced, for example, 'I feel more certain of the limb I have lost than the one I have kept' (Pelletier, 1905b: 281). The effect of the phantom limb on her actively irrational patients was to feed their persecution complex. For example, a paranoid patient accounted for the pains felt in a non-existent limb by the alleged desire of hospital staff to punish him.

Pelletier's primary interest was not in the admittedly curious anecdotal material derived from her small selection of patients - we note that she seems to have enjoyed a good rapport with them - but in the theoretical questions relating a powerful illusion based on physical causes (nerves, brain function) to abnormal states of mind, processes that can also be observed in sane people. What she termed the 'incoherence of the individual' did not add up to madness yet was manifested whenever one analysed prejudices. Her case studies offer evidence of the ways irrational ideas influence the sane as well as the insane, accounting for the resistance of otherwise rational people to arguments for social improvement, as, for example, for improvements in the position of women.

Although Pelletier's research as a psychiatric intern was largely analytic and diagnostic, she also participated in more interventionist modes in therapeutic practice. Patients were given experimental doses of substances, to test therapeutic potential. ${ }^{11}$ Her contributions, with Dr Marie, to this school of heroic medicine were 'Le sérum marin dans la thérapeutique des aliénés' (Pelletier and Marie, 1905) and 'Le mal perforant dans la paralysie générale' (Marie and Pelletier, 1905b). Basing their study on a work by M. Quinton, $L^{\prime}$ 'Eau de mer, milieu organique, ${ }^{12}$ which argued that human plasma in its chemical composition is similar to sea water, Pelletier and Marie experimented on their patients by giving them injections of 'sea serum' with the aim of restoring the chemical balance of their bodies and minds.

Pelletier accepts that her sérum marin can only be beneficial in cases where cerebral function is deranged but not destroyed. Cases of general paralysis do not respond to this treatment. The claim for the effectiveness of this therapy on melancholics and maniacs was that it assisted convalescence, improved appetite and helped excretory functions.

'Le mal perforant dans la paralysie générale', based on 91 examples, three given in some detail, looks at perforating ulcers of the foot in patients suffering from general paralysis (general paresis). It is assumed that where remission from general paralysis operates, there is a link between first the outbreak, then the healing of perforating ulcers and amelioration in the patient's condition in 
general paralysis. While agreeing that some sores of this nature can be linked to pressure, as in bed sores, Marie and Pelletier believe they are connected to nerve damage of the central nervous system. To test their hypothesis, the authors provoked sores artificially in their patients to see if there was a corresponding improvement in general paralysis. With engaging honesty they admit there is not: 'Unfortunately, the results from this therapy have not been encouraging and we have only had failures to record' (Marie and Pelletier, 1905b: 476).

In 1906 Pelletier presented a paper to the IGP, analysing cases of hypochondria where patients believed they were being devoured either internally or externally by microscopic creatures (Pelletier, 1906b). ${ }^{13}$ She followed in the positivist tradition of Charles Richet whose, Les Démoniaques d'aujourd'hui and Les Démoniaques d'autrefois (Richet, 1880), compared nineteenth-century hysterical and somnambulistic patients with those accused of demonic possession in medieval times. Richet showed that behaviour which would have been punished by death in the past was now treated as a disease (Hecht, 2003: 246-9; Parot, 2000: 4-6; Richet, 1880: 341).

Pelletier, too, historicized mental illness, arguing that hypochondriacs explained their symptoms in the language appropriate to their cultural moment (Pelletier, 1906b: 61). In the past, wild beasts, such as a leopard or a tiger, had been frequently imagined as agents of possession among primitive peoples (p. 65). In the Middle Ages 'the possessed' described identical sensations but gave a demonic explanation for them such as the belief that 6666 devils were lodged in their bodies (p. 66).

It was also in her internship period that Pelletier wrote and published two articles drawing on her anthropological and psychiatric experience: ' $\mathrm{La}$ prétendue infériorité psycho-physiologique des femmes' (Pelletier, 1904c) and 'La prétendue dégénérescence des hommes de génie' (Pelletier, 1905c). ${ }^{14}$ The former was her first avowedly feminist pamphlet, the second an attack on Lombroso's theories on genius. The latter parallels Constance Pascal's article on Schumann (Pascal, 1908) querying the Lombrosian equivalence of genius and madness. In these articles Pelletier used her medical and psychiatric training and her commitment to neo-Lamarckian evolutionary theory to validate a feminist agenda, as well as a tool to attack the underlying anti-feminism of allegedly objective and liberal-minded scientists.

'The alleged degeneration of men of genius' (1905c) demonstrates Pelletier's awareness of the limitations inherent in aspects of the scientism of her day. Pelletier unpicks the implications of Lombroso's theories from the perspective of J. S. Mill's liberal individualism. ${ }^{15}$ Difference, eccentricity, or revolutionary opinion could all, according to Lombroso, constitute the marks of madness and degeneracy. She begins with that traditional device of masculine learning, the Latin tag: Nihil est ingenium sin aliqua stultitia (There is nothing of genius without some stupidity). ${ }^{16}$ Admitting that Lombroso's renown stemmed from the prevalent scientific belief in materialist conceptions of the mind, she suggested that one should separate idealist theories of the mind (which 
she also rejected) from a reductive understanding of human potential given a materialist standpoint. Although the tendency to rehabilitate the body at the expense of the soul had its basis in Enlightenment philosophy (here Pelletier cites George Cabanis's Rapports du physique et du moral de l'homme, 1802), she argues that now we study great men such as Napoleon, Chopin, Musset and Comte, not for their ideas or their genius and originality, but to focus on their illnesses or weaknesses.

Cases of madness in great minds merely demonstrate that genius is not immune from madness any more than from cancer or tuberculosis. As for the alleged moral degeneracy of geniuses, who are said to be egotists, bad husbands, neglectful and cruel fathers, haughty, despotic and selfcentred, no mention is made of the fact that these qualities are very frequently found in individuals of average or below-average intelligence. (Pelletier, 1905c: 8)

Men of genius are disliked, she believes, because they are not average, because they stand out from the crowd. The effect of Lombrosian theories of degeneracy has been to glorify mediocrity. Above all, Pelletier defends genius as the key instrument of social change.

Pelletier's theory of social evolution, imbibed from her anthropological studies, gave her a model to argue for change. She returned to the theme that genius is a product of social forces as much as of innate talents in 'Les facteurs sociologiques de la psychologie féminine', where she drew on psychology and its social determinants to establish the social conditioning underlying women's oppression (Pelletier, 1907a). And in La Suffragiste (Pelletier, 1913a) she evoked her own sense of missed opportunities and baulked ambition: 'But a poor woman, who wants to succeed solely on her own merits would, even today, find insurmountable obstacles.'

'The assumed psycho-physiological inferiority of women' (Pelletier, 1904c) unpicks those irrational or prejudicial ideas enshrined in the science of measurement and objective description. In this feminist critique of the social sciences, Pelletier lays out the major themes of later works: social progress in evolutionary terms; irrational prejudice masquerading as scientific authority; social construction of gender identity; and the inculcation of dependency central to women's education. Pelletier seems to have been deliberately breaking with her anthropological mentors, especially Léonce Manouvrier ('anything but a feminist'). She aimed to expose the depth of underlying prejudice, 'the age-old contempt against women' (Pelletier, 1904c: 3) evinced in the writings of Broca and of Le Bon, or implicitly in the construction of the hysterical personality by psychiatrists and psychologists such as Richet, Charcot, Janet and Dumas, who looked for women's 'weakness' in female physiology and psychology.

Assumed in Pelletier's discussion are theories of progress, of the primitive and of the stages of culture (Bowler, 1989; Goody, 1989; Gordon, 1996; Gould, 1977; Kuper, 1988; Maine, 1861; Morgan, 1877; Mortillet, 1881). 
In present-day society, she suggests, the latter is represented by 'primitive peoples' (les peuples sauvages), the lumpen proletariat and the working class, whose sexual attitudes have evolved scarcely at all. Pelletier's tacit acceptance of racial hierarchies here, while unsurprising for the period, was to be greatly modified over time (Pelletier, 1932). That she did not invoke the perspective of the monogenisists, so clearly exemplified in the 1911 Universal Congress on Race, suggests that she was still heavily influenced by the Euro-centrism of French anthropological theory.

To some extent, Pelletier accepts that women's present subordination constitutes an adaptive failure, or rather is a sign of enforced adaptation. When women are accused of lacking a sense of honour, of being manipulative, vain or self-seeking (qualities not unknown in men), it is because these very qualities are weapons in the struggle for survival. Women's education, even if embracing higher education, is seen as an embellishment (une parure) to enable them to attract husbands, not to assume control over their own lives, the major goal of education for boys. Pelletier had identified women's collusion in their own oppression as the key to the problem of bringing about women's emancipation. It was a theme appropriated some forty years later by Simone de Beauvoir in The Second Sex.

Between 1900 and 1906, the period covered in this paper, apart from her highly commended dissertation, Pelletier wrote, or co-authored, at least twelve articles on anthropological or psychological subjects based on her hospital work. Although these articles develop the theoretical positions adopted in her dissertation, they are not merely culled from it and show her interest in expanding into new areas of research, taking a neo-Lamarckian perspective into the relationship between mental illness and social conditions (Pelletier, 1906a; Sowerwine and Magnien, 1992: 46).

Pelletier's sociological concerns are well illustrated by 'Madness and mental/ emotional shocks' (Pelletier, 1906a). This case study of a watch-maker from Rodez reads more like a short story by Maupassant than the classic clinical studies appearing more usually in psychiatric literature. Instead of briefly detailing the patient's background in tabular form (as in 'Le mal perforant') age, marital status, heredity, previous illnesses - Pelletier constructs a narrative of tragic failure in adaptation, which also conveys a politicized view of her patient's situation. Her thesis contests the prevalent psychiatric view that the causes of mental breakdown were fundamentally hereditary and that violent emotional shocks have little or only minor bearing on the hereditary weakness.

The case concerns the vicissitudes of a provincial watch-maker, M., caught between rival political factions in the town: the clerical and anti-clerical interests. The unfortunate watch-maker, who has no interest in politics and who only wishes to make a peaceable living, is mercilessly drawn into the town's ideological conflicts. Threatened with a trade boycott from the head of the local seminary if he does not vote for the clerical party in the forthcoming 
elections, he gives in to blackmail only to earn the odium of the anti-clericals, who in turn also boycott his shop, as does the clerical party, saying he is not to be trusted (Pelletier, 1906a: 191). M.'s business collapses, he attempts suicide and suffers a breakdown.

Pelletier's interest in these machinations stems in part from her deepseated anti-clericalism. Though the free-thinking, Masonic faction in Rodez bullies the watch-maker, just as cruelly and arbitrarily as do the priests, her narrative places far less emphasis on the former than the latter. Nevertheless, the effect of these pressures on a man of average abilities and temperament is devastating. Pelletier (1906a: 192) accepts that someone of more resilient temperament might have survived. But there is no need to insist on hereditary predispositions in a situation in which the individual is confronted by unbearable conflicts and contradictions. Extreme emotion played a precipitating role in mental breakdown. One imagines that Pelletier's choice of a man, not a woman showing the effects of emotional trauma partly reflected a desire not to add to the voluminous literature alleging female hysteria and mental instability.

\section{Conclusion}

It seems appropriate to revisit the circumstances surrounding Pelletier's exit from a psychiatric career, and her abandonment of medical research. In 1906 her seemingly unstoppable advance in psychiatric medicine received an abrupt and catastrophic check when she narrowly failed the qualifying examination, the concours d'adjuvat (Gordon, 1990: 69-71; Sowerwine and Maignien, 1992: 47-52). She was precluded from re-sitting it the following year, as the decreed age limit was thirty-two.

This failure was a terrible blow to Pelletier's ambitions. What had seemed to be a promising and financially secure career in the psychiatric service was now closed to her. In her short unpublished autobiography, she glossed over this setback, but recalled her experience as a psychiatric intern with some bitterness: 'At the asylum, the male interns warred with me constantly, so I only came for my morning shift. It wasn't possible to work at [experimental] psychology there.' (Pelletier, 'Doctoresse Pelletier, mémoires d'une féministe', 15). From her publication record, it seems clear that Pelletier certainly exaggerated in saying that one could not do research, but she did encounter hostility from male interns. At this period she broadcast her feminist convictions by her hair style (cut short) and her mannish jackets. One colleague, a Dr Courbon, remarked that she was 'obsessed by her theory of the absolute equality of the sexes'. ${ }^{17}$ She evidently did not hesitate to debate her ideas on sexual equality with all comers.

When in that fateful January of 1906 Pelletier had applied for permission to sit the concours d'adjuvat for admission to the psychiatric service, she had initially been turned down on the grounds that, like all women, she lacked the full citizenship rights required for entry. (This was more or less a replay of 
her experience in applying for the right to sit the examination as a psychiatric intern.) Pelletier thereupon applied for a dérogation (dispensation), assuming that official wheels would turn slowly and that she would be admitted for the next series of examinations in 1908. Unexpectedly, permission was granted immediately and she was confronted with the necessity of sitting the exams in March with only one month to prepare. Her failure, by four points (she gained 26 out of the 30 needed for a pass mark) must have been an utterly crushing blow. What is particularly questionable is that she gained only 6 out of a possible 10 points in the publications section test (Sowerwine and Magnien, 1992: 46-50). In the light of her impressive publication record and her dissertation, this seems surprising, as Sowerwine and Magnien argue; one could go further, and say it was unjust.

Whether or not there was animosity or prejudice against her from her examiners, and whether her feminist activity among Freemasons could have prejudiced Masonic members of the jury against her, the fact was that her failure condemned her to a minor role in medicine as a general practitioner and as a night doctor for the Post Office and Telegraph. Her redoubtable energies thereafter were directed into socialist and feminist politics (Gordon, 1990; Sowerwine and Magnien, 1992). A police report (AN, 1916) summarizes her career after leaving the psychiatric service until the outbreak of World War I:

A militant feminist, before the war the above named frequented revolutionary and anti-militarist circles and was president of the feminist group, La Solidarité des Femmes, a group which has died out since the beginning of hostilities. She gave lectures on neo-Malthusianism ... A Member of the P.S.U. [Parti Socialiste Unifié], she presented herself under the auspices of this party as a candidate to the legislative elections of 1910 in the 8th arrondissement and to the municipal election of 1912 in the St. Thomas Aquinas quarter. She obtained an insignificant number of votes. Since the war she has kept in the background, but she nevertheless attends meetings organised by the 5 th section of the P.S.U. ... and attended a pacifist meeting held 22 January last at the Café Voltaire, place de l'Odéon, which allows one to suppose that she has decided to take up her role as a militant and that she intends to take part in the present pacifist movement.

Pelletier's police file reflects the surveillance culture of the Third Republic: every meeting whether of feminists, socialists, anarchists or pacifists, would have had its police spy in attendance. Pelletier's most notorious act at this period was at a demonstration on 16 July 1908, when she broke a window at a polling station in protest against women's exclusion from the vote (Fig. 2), in the hope that arrest would lead to the kind of publicity and hunger strikes undertaken by English suffragettes; this is dismissed in a one-line comment in her police report as merely attracting a fine of sixteen francs.

Could Madeleine Pelletier have thrived as a hospital psychiatrist? Bearing in mind that initially she would almost certainly have been assigned to a provincial asylum, taking her away from her Parisian roots and her political contacts, and 


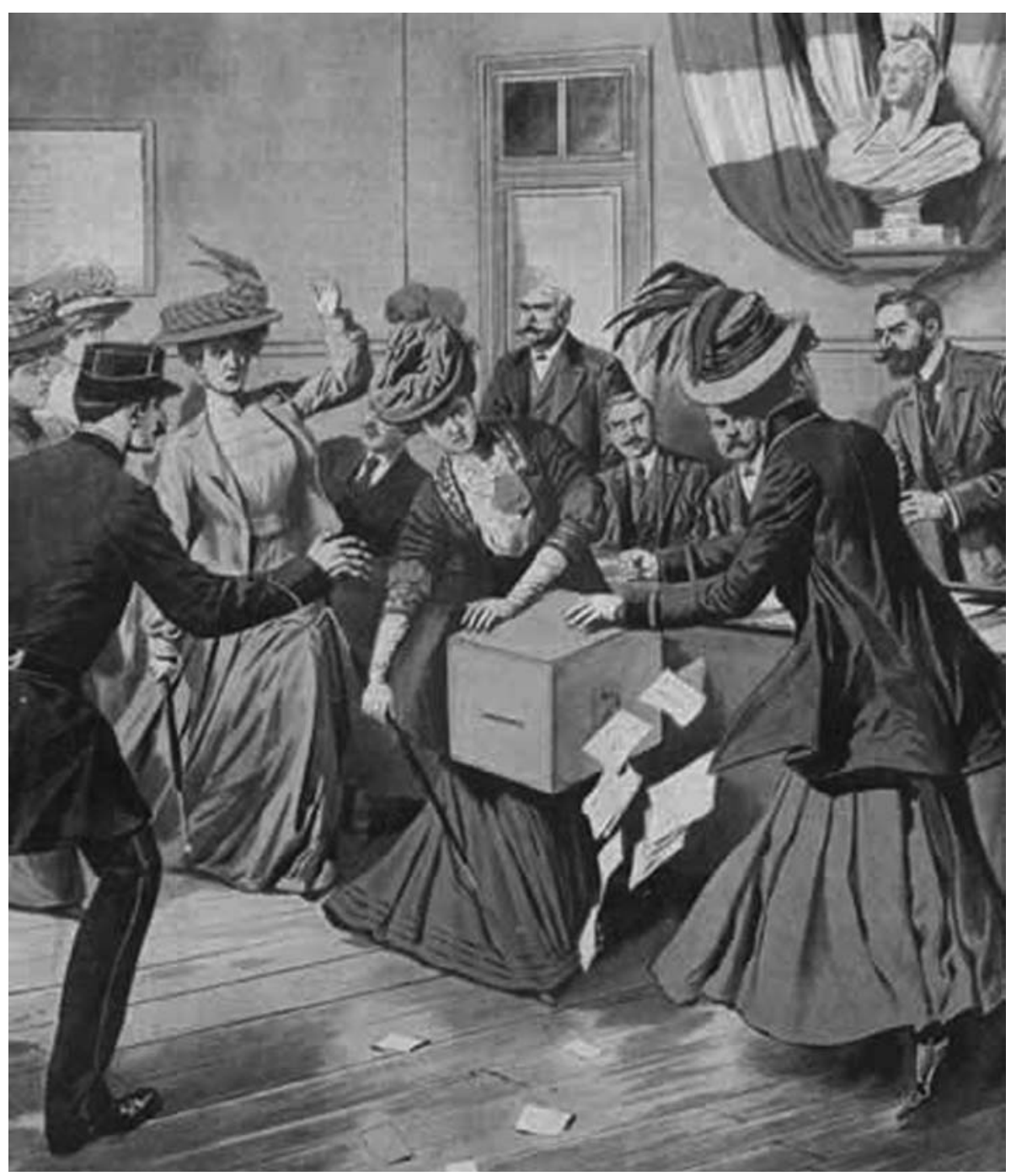

FIG. 2. Madeleine Pelletier and Hubertine Auclert overturning a ballot box in the 1908 French elections in protest against women's exclusion from the suffrage (courtesy of the Mary Evans Picture Library)

that asylum doctors were required to live on site, closely supervised in their private as well as their professional lives, it is difficult to see her in that context. When one reflects on her uncompromising personality, her conscious decision to debate, or as some would have said to broadcast, her views, both feminist and socialist in whatever milieu she found herself, her mannish dress code and her refusal to play a feminine role, one can imagine that life as an asylum 
doctor might have been difficult. As Constance Pascal discovered at Clermont de l'Oise, it was not working with the patients that sapped her energy and resolve, but the petty restrictions and lack of reforming zeal on the part of the administration, as well as the personal surveillance to which she was subjected (Gordon, 2006). Whether Pelletier, fully engaged in a psychiatric career, would have modified her political militancy cannot be known, but it seems unlikely. She was driven by a passionate desire to change the society into which she had been born, one of grinding poverty and intellectual deprivation, where women were treated with contempt.

Much of Pelletier's voluminous writing after 1906 - journalism, polemical articles, novels, short stories, plays and feminist theoretical works - deals with poverty and social neglect and how these impact on the working class, and especially on women. Her writings, lucid, logical and displaying a dry wit, ranged from works on women's education, to the right to abortion, to advocating revolution (Pelletier, $1907 b, 1913 b, 1914)$. Her career in Freemasonry, socialist politics and feminism was never free from controversy (Mitchell, 1989). The drawing of Pelletier, done late in her life (Fig. 3), shows a belligerent, aging figure. It forms a poignant contrast to the confident, mannish, almost defiant, studio portrait of the young Madeleine, with her cropped hair, severely tailored jacket, cravat, watchchain and unsmiling, determinedly uncoquettish gaze (see Fig. 1). Pelletier's undoubted intelligence, her political passion and her radical sense of women's social and psychological subjection - what one could term her genius - never found an adequate outlet. As she remarked in 'Le génie

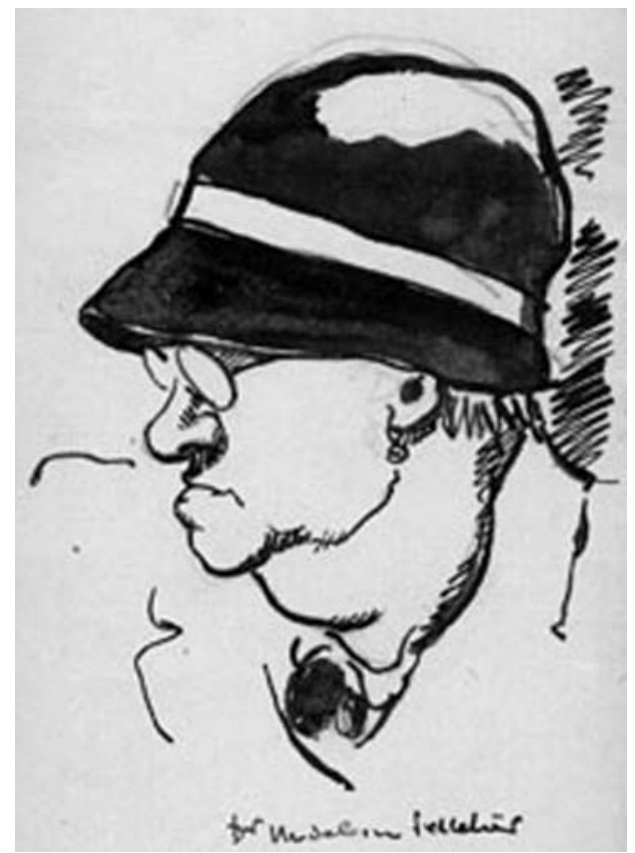

FIG. 3. Drawing of Madeleine

Pelletier by Jean Texcier, c.1937

(source: L'OURS 'L'Office Universitaire de Recherche Socialiste ${ }^{18}$ ) et la femme':

A woman of great merit has everyone and everything against her. Men loathe her with that racial hatred that Americans show for the black man who dares to wear a white collar; as for the women, they detest her because she is liberated from the servitude under which they all cower. If a woman of merit has money, she can still hope that she will be allowed a little success. If she is pretty and easy-going, she can, by the protection of men who 
will have bought her vile complaisance, succeed in certain areas, especially in literature. But a poor woman who wishes to succeed by her own merit alone will find ranged against her, still today, unconquerable obstacles. How can one imagine in these conditions that genius, being already so rare among men, should manifest itself in a woman?

Genius is not that 'grace' of the Jansenists: inventions do not spring fully fledged from the brain. If Newton was the discoverer of gravity, that is because he was an astronomer. If Claude Bernard discovered the function of the liver, it is because he was a physiologist. If Napoleon had been an entomologist instead of a general, he would never have conquered Europe. (Pelletier, 1913a)

Pelletier recognized the sociological determinants of her situation and that of other women, but she did not accept them with resignation. If she felt she was the potential genius who lacked the proper social context, she militated throughout her life in the cause of women and the working class, though often she seemed to despise the very constituency that she sought to serve. She could well, if she had remained in psychiatry, have contributed a greater social understanding of mental illness. Nevertheless, her career as a militant feminist and socialist was creative and inspiring. Although she did not see French women gaining the vote in her lifetime, nor winning reproductive rights for which she had long campaigned and for which she was eventually martyred, her medical and psychiatric training formed the scientific and rationalist grounding for her lifelong career of political militancy.

\section{Notes}

1. For the complex history of evolutionary thought in France, the evolution and appropriation of Lamarck's ideas and their political dimensions, see: Bowler, 1996; Burkhardt, 1984; Conry, 1974; Corsi, 1988; Gordon, 1990; Heyer, 1982; Jordanova, 1984; Letourneau, 1888, 1892; Nye. 1984.

2. Held at the Bibliothèque Historique de la Ville de Paris.

3. Held at the Bibliothèque Marguerite Durand.

4. Similarly her citing of Anglophone philosophers in her doctoral thesis - William James, John Stuart Mill and Herbert Spencer - depended on their works being available in French translations.

5. For a less positive view, see Martin S. Staum's (2003) review of The End of the Soul, in which he calls Manouvrier a 'half-hearted feminist'.

6. Craniometry as a 'science' was fully discredited during the period of Pelletier's involvement in anthropological research. Both she and Manouvrier 'moved on' (Gordon, 1990: 36-40; Hecht, 2003: 211-27).

7. Vaschide and Pelletier's research was demolished by Karl Pearson (1902: 108). 'Frankly we consider that the memoir is a good illustration of how little can be safely argued from meagre data and a defective statistical theory'.

8. The second edition of Pelletier's dissertation (1904b) was re-titled: Les Lois morbides de l'association des idées. I wish particularly to thank Professor German E. Berrios for making a copy of the second edition available to me. Quotations from Pelletier's dissertation are from the second edition which is identical to the first. 
9. For the history of hysteria and its gendered implications see: Gilman, King, Porter, Rousseau and Showalter, 1993; Goldstein, 1987; Ripa, 1990; Showalter, 1987.

10. One of the most intriguing items in the Bulletin de l'Institut Général Psychologique was a report of an international conference held in London on race (Anon., 1911). Departing markedly from contemporary hierarchical studies on race, this conference stressed racial harmony, and equality between peoples.

11. For experimental treatments on psychiatric patients, see, for example: Buvat-Pochon, 1939; Pascal Vié and Agasse, 1929.

12. I have been unable to trace this.

13. This paper was discovered in October 2006 by the present author, when undertaking research for this study. To my knowledge it has not previously been analysed by historians.

14. Pelletier remained preoccupied with the theme of genius, subsequently publishing Les Femmes peuvent-elles avoir du genie (n.d.) and 'Le génie et la femme'(1913a).

15. See Lombroso, 1891. (Lombroso had previously published Genia e Follia in 1884 and subsequently L'Uomo i genio in rapporto alla psichiatria alla storio e d'ell'estetica and Genio e degenerazione in 1897, indicating his continuing preoccupation with the subject.) Manouvrier and Legrain had attacked Lombroso's theories at the Paris congress of the Anthropological Society of Paris in 1889 and the Brussels congress of 1892. The debate was between those who wished to place anthropology in evolutionary transformist discourse and those who stressed innate human qualities (Legrain, 1892).

16. I have not been able to trace the source of this quotation but it resembles - though with a significant difference - Seneca: De Tranquillitate Animi, 17, 10: nullum magnum ingenium sine mixtura dementiae fuit. (There was no great genius without a tincture of madness.)

17. Dr Courbon, unpublished MS, courtesy of Dr Jacques Chazaud, Pascal/Rees Family Papers, quoted in Gordon, 2006: 164.

18. Retrieved (17 January 2008) from the L'OURS Archive: http://www.lours.org/default. asp?pid $=214$.

\section{References}

Allen, J. S. (2003) Sisters of another sort: Freemason women in modern France 1725-1840. Fournal of Modern History, 75 (4), 783-835.

Anonymous (1911) Le Premier Congrès Universel des Races: sommaire. Bulletin de l'Institut Général Psychologique, (3-4), 173-347.

Archives Nationales [AN] (1916, February) Police report, F7 13961.

Bergson, H. (1901) Essai sur les données immédiates de la conscience (Paris: Félix Alcan).

Blanckaert, C. (1989) L'indice céphalique et l'ethnogénie européenne: A. Retzius, P. Broca, F. Pruner-Bey (1840-1870). Bulletins de la Société d'Anthropologie de Paris, 1 (3-4), 165-202.

Bowler, P. J. (1989) The Invention of Progress: The Victorians and the Past (Oxford: Basil Blackwell).

Bowler, P. J. (1996) Life's Splendid Drama (Chicago and London: University of Chicago Press).

Burkhardt, R. W., Jr. (1977) The Spirit of System: Lamarck and Evolutionary Biology (Cambridge, MA and London: Harvard University Press).

Burkhardt, R. W., Jr. (1984) The zoological philosophy of J. B. Lamarck. In J. B. Lamarck, Zoological Philosophy (Chicago and London: University of Chicago Press), xv-xxxix.

Buvat-Pochon, C. (1939) Les Traitements du choc d'autrefois en psychiatrie (Paris: Librairie le François).

Cabanis, P.-J.-G. (1802) Rapports du physique et du moral de l'homme (Paris: Crapart, Caille et Ravier). 
Conry, Y. (1974) L'Introduction du Darwinisme en France au XIXe siècle (Paris: J. Vrin).

Corsi, P. (1988) The Age of Lamarck, trans. Jonathan Mandelbaum (Berkeley, Los Angeles and London: University of California Press).

Darwin, C. (1862) De l'Origine des espèces ou les Lois du progrès chez les êtres organisés. Traduit en français par Mlle Clémence-Auguste Royer (Paris: Guillaumin); originally published in English in 1859.

Dumas, G. (1899) Revue critique: névroses et idées fixes. Revue Philosophique de la France et de l'Etranger, 47, 646-68.

Fraisse, G. (1985) Clémence Royer (Paris: Le Découvert)

Gilman, S., King, H., Porter, R., Rousseau, G. S. and Showalter, E. (1993) Hysteria Beyond Freud (Berkeley, Los Angeles and London: University of California Press).

Goldstein, J. (1987) Console and Classify: The French Psychiatric Profession in the Nineteenth Century (Cambridge: Cambridge University Press).

Goody, J. (1989) The Oriental, the Ancient and the Primitive (Cambridge: Cambridge University Press).

Gordon, F. (1990) The Integral Feminist: Madeleine Pelletier, 1874-1939 (Cambridge: Polity Press).

Gordon, F. (1992) Les femmes et l'ambition: Madeleine Pelletier et la signification d'une autobiographie féministe. In C. Bard (ed.), Madeleine Pelletier (1874-1939): Logique et infortunes d'un combat pour l'égalité (Paris: Côté-femmes), 27-34.

Gordon, F. (1996) Anthropological analogies: Edith Simcox and Madeleine Pelletier. In C. Campbell Orr (ed.), Wollstonecraft's Daughters: Womanhood in England and France 1780-1920 (Manchester and New York: University of Manchester Press), 168-85.

Gordon, F. (2006) French psychiatry and the new woman: the case of Dr Constance Pascal, 1877-1937. History of Psychiatry, 17(2), 150-82.

Gould, S. J. (1977) Ontogeny and Phylogeny (London: Harvard University Press).

Hammond, M. (1980) Anthropology as a weapon of social combat in late nineteenth-century France. Fournal of the History of Behavioural Sciences, 16, 118-32.

Harvey, J. (1997) 'Almost a Man of Genius': Clémence Royer, Feminism and Nineteenth-century Science (New Brunswick: Rutgers University Press).

Hecht, J. M. (2003) The End of the Soul: Scientific Modernity, Atheism and Anthropology in France, 1876-1936 (New York: Columbia University Press).

Heyer, P. (1982) Nature, Human Nature and Society: Marx, Darwin, Biology and the Human Sciences (Westport, CT, and London: Greenwood Press).

Janet, P. (1898, 1903) Les Obsessions et la psychasténie (Paris: Félix Alcan).

Jordanova, L. J. (1984) Lamarck (Oxford: Oxford University Press).

Kuper, A. (1988) The Invention of Primitive Society (London: Routledge).

Laurent, G. (1987) Paléontologie et évolution en France de 1800-1860: une histoire des idées de Cuvier et Lamarck à Darwin (Paris: Edition du CTHS).

Laurent, G. (1989) Idées sur l'origine de l'homme en France de 1800 à 1871 entre Lamarck et Darwin. Bulletins de la Société d'Anthropologie de Paris, 1 (3-4), 105-30.

Lefebvre, T. (2002) Occultisme la méthode graphique. Bulletin la Sémia, 1, 6.

Legrain, P. M. (1892) L'anthropologie criminelle au Congrès de Bruxelles de 1892. La Revue scientifique, (oct.), 487-97.

Letourneau, C. (1888) L'Évolution du marriage et de la famille (Paris: A. Delahaye et É. Lecrosnier).

Letourneau, C. (1892) Property, its Origin and Development (London: W. Scott).

Lombroso, C. (1891) The Man of Genius (London: W. Scott); originally published as Uomo de Genio in 1888.

Maine, H. (1861) Ancient Law its Connection with the Early History of Society, and its Relation to Modern Ideas (London: J. Murray). 
Manouvrier, L. (1883) Sur la grandeur du front et des principales régions du crâne chez l'homme et chez la femme. Bulletins et Mémoires de la Société d'Anthropologie de Paris, 6, $69-98$.

Manouvrier, L. (1903) Conclusions générales sur l'anthropologie des sexes et ses applications socials. Revue de l'École d'Anthropologie de Paris, 13, 405-23.

Marie, P. and Pelletier, M. (1905a) Craniectomie et regénération osseuse. Bulletins de la Société d'Anthropologie de Paris, 7, 369-73.

Marie, P. and Pelletier, M. (1905b) Le mal perforant dans la paralysie générale. Revue de Psychiatrie et de Psychologie Expérimentale, 4e série (9), 469-76.

Mill, J. S. (1865) An Examination of Sir William Hamilton's Philosophy (London: Longman, Green, Roberts and Green).

Mitchell, C. (1989) Madeleine Pelletier: the politics of sexual oppression. Feminist Review, 33, 72-91.

Morgan, L. H. (1877) Ancient Society (London: Macmillan).

Mortillet, A. de (1881) Les Débuts de l'humanité (Paris: Droin).

Nye, R. A. (1975) The Origins of Crowd Psychology: Gustave Le Bon and the Crisis of Mass Democracy in the Third Republic (London and Beverly Hills: Sage Publications).

Nye, R. A. (1984) Crime, Madness and Politics in Modern France (Princeton: Princeton University Press).

Parot, F. (2000) Cent ans de Société de Psychologie en France. Psychologie Française, 45 (1), 3-11.

Pascal, C. (1908) Les maladies mentales de Robert Schumann (génie et démence). fournal de Psychologie Normale et Pathologique, 5, 98-130.

Pascal, C., Vié, J. and Agasse, P. (1929) Guérison rapide d'une influencée catatonique à la suite de vaccination anti-typhique. L'Encéphale, 316-19.

Paulhan, F. (1887) Les Phénomènes affectifs et les lois de leur apparition (Paris: F. Alcan).

Pearson, K. (1902) On the correlation of intellectual ability with the size and shape of the head. Proceedings of the Royal Society of London, 71, 106-14.

Pelletier, M. (1900) Recherches sur les indices pondéraux du crâne et des principaux os longs d'une série de squelettes japonaises. Bulletins de la Société d'Anthropologie de Paris, (15 nov.), 514-29.

Pelletier, M. and Marie, P. (1901) Sur un nouveau procédé pour obtenir l'indice cubique du crâne. Bulletins de la Société d'Anthropologie de Paris, 2, 188-93.

Pelletier, M. (1903a) Contribution à l'étude de la phylogénèse du maxilaire inférieure. Bulletins de la Société d'Anthropologie de Paris, 3, 537-45.

Pelletier, M. (1903b) L'Association des idées dans la manie aiguë et dans la débilité mentale (Paris: J. Rousset).

Pelletier, M. (1904a) L'écho de la pensée et la parole intérieure. Bulletin de l'Institut Général Psychologique, (Séance du 6 mai), 440-73.

Pelletier, M. (1904b) Les Lois morbides de l'association des idées, 2nd edn [of L'Association des idées] (Paris: Jules Rousset).

Pelletier, M. (1904c) La prétendue infériorité psycho-physiologique des femmes. La Vie Normale, 1 (10), 1-6.

Pelletier, M. (1905a) Admission des femmes dans la Franc-maçonnerie. L'Acacia: Revue d'Études Maçonniques, 27, 178-89.

Pelletier, M. (1905b) Les membres fantômes chez les amputés délirants. Bulletin de l'Institut Général Psychologique, (Séance du 14 avril), 280-90.

Pelletier, M. (1905c) La prétendue dégénérescence des hommes de genie. L'Acacia, [exact details not found].

Pelletier, M. and Marie, P. (1905) Le sérum marin dans la thérapeutique des aliénés. Archives de Biothérapie, (20 mai), 49-64. 
Pelletier, M. (1906a) Folie et choc morale. Archives de Neurologie, 2e série (20), 188-92.

Pelletier, M. (1906b) L'origine coenesthésique des idées hypocondriaques microzoomaniaques. Bulletin de l'Institut Général Psychologique, (Séance du 12 janvier, 6e année), 1, 61-76.

Pelletier, M. (1907a) Les facteurs sociologiques de la psychologie féminine. La Revue Socialiste, (juin), 508-18.

Pelletier, M. (1907b) Comment préparer la révolution. La Guerre Sociale, (14 août).

Pelletier, M. (1913a) Le génie et la femme. La Suffragiste, 5e année, 40 (juillet), 1-3.

Pelletier, M. (1913b) Pour l'abrogation de l'article 317. Le Droit à l'avortement (Paris: édition du Malthusien).

Pelletier, M. (1914) L'Éducation féministe des filles (Paris: Giard et Brière).

Pelletier, M. (1932) Une Vie nouvelle (Paris: Figuière).

Pelletier, M. (n.d.) Les Femmes peuvent-elles avoir du génie (Paris: Publication de La Suffragiste).

Pelletier, M. (n.d.) Mémoires d'une féministe [unpublished]. Fonds Bouglé, Bibliothèque Historique de la Ville de Paris.

Quétel, C. (1990) History of Syphilis (Cambridge: Polity Press).

Richet, C. (1880) Les démoniaques d'aujourd'hui. Revue de Deux Mondes, 33 (3), 340-72.

Ripa, Y. (1990) Women and Madness: The Incarceration of Women in Nineteenth-century France, trans. C. du Peloux Menagé (Cambridge: Polity Press).

Rogues de Fursac, J. (1904) Revue critique de l'Association des idées. Revue Philosophique de la France et de l'Étranger, 57 (jan.-juin), 671-3.

Rogues de Fursac, J. (1914) Étude statistique sur les antécédents héréditaires de paralytiques généraux. Annales Médico Psychologiques, 4, 1-20.

Royer, C. (1895) Diminution de la population en France. Bulletins et Mémoires de la Société d'Anthropologie de Paris, 4e série, 6, 653-6.

Shorter, E. (2005). A Historical Dictionary of Psychiatry (Oxford: Oxford University Press).

Showalter, E. (1987) The Female Malady: Women, Madness and English Culture, 1830-1980 (London: Virago Press).

Sowerwine, C. (2003) Woman's brain, man's brain: feminism and anthropology in late nineteenth-century France. Women's History Review, 12 (2), 289-367.

Sowerwine, C. and Maignien, C. (1992) Madeleine Pelletier, une féministe dans l'arène politique (Paris: Éditions Ouvrières).

Spencer, H. (1855) The Principles of Psychology (Longman: Longman, Green, Roberts and Green).

Staum, M. S. (2003) Review of The End of the Soul. H-France Review, 3 (Oct.), 107.

Stebbins, R. E. (1974) France. In T. F. Glick (ed.), The Comparative Reception of Darwinism (Austen, TX, and London: University of Texas Press).

Stewart, M. L. (2000) For Health and Beauty: Physical Culture for French Women 1880s-1930s (Baltimore: John Hopkins University Press).

Vaschide, N. and Pelletier, M. (1904) Recherches expérimentales sur les signes physiques de l'intelligence (La Chapelle-Montligeon, Orne: Imprimerie de Montligeon).

Ward, J. (2002) Le malade mental étranger durant l'entre-deux-guerres: une double aliénation médico-administrative. Actes de l'Histoire de l'Immigration, (nov.), 1-14. 